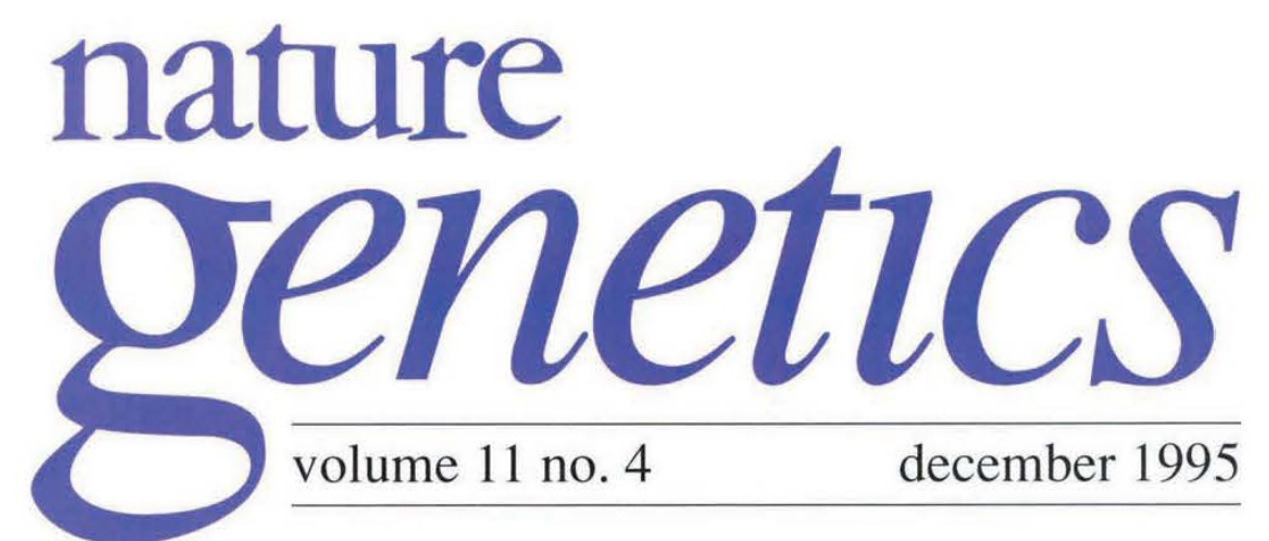

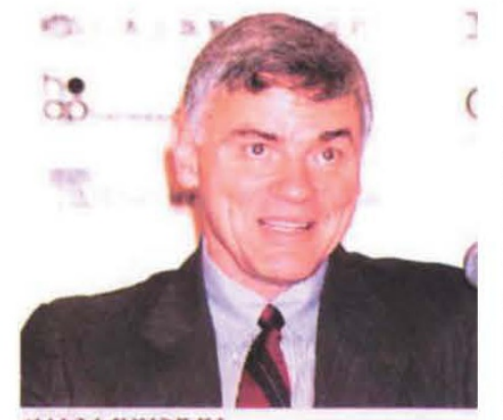

and vivisur

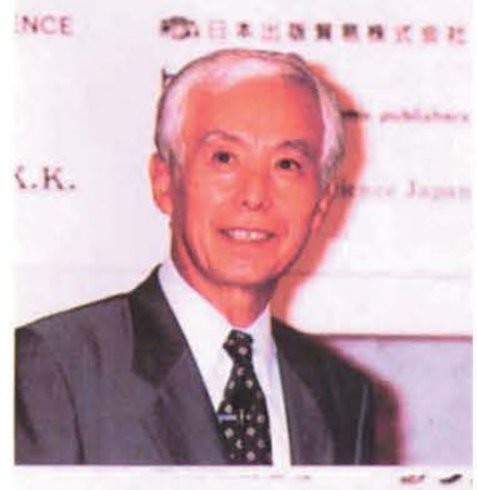

30

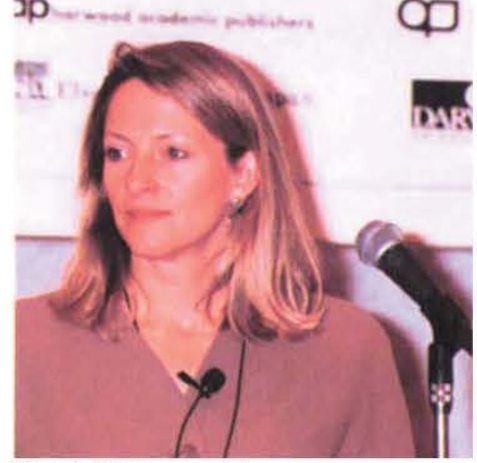

Hood, Matsubara, Bowcock.

"Vantures in Gonetics: Advancos and Apptications in Reseserch and Technology

16-17 Oetober 1995, Tokyo, Japan. Organized by

Nature Gonetics and Nature Japan KK. PPatrons

- MiTI, Sctence and Technology Agency, dapan.)

\section{Ventures made in Japan}

Last month's news that two of Japan's biggest government agencies -- the Ministry of International Trade and Industry (MITI) and the Ministry of Health and Welfare (MHW) - are planning to launch two venture capital biotechnology companies in Japan, caught many observers by surprise. For decades and for decidedly varied reasons, Japan has failed to capitalize (no pun intended) on its undoubted strengths in basic research and technology in the establishment of private research ventures. One result is that Japan is about 5 years behind the United States and Europe in genome research. Now, perhaps, there is a chance to close the gap. It would be nice to think that the Nature Genetics conference on Ventures in Genetics held in Tokyo* before an audience of over 400 people, just two weeks before that report, had a little to do with it.

Unlike Japan, the United States has witnessed an explosion in the growth of private gene discovery companies seeded with venture capital. As stressed by Leroy Hood (U. Washington), small start-up companies are essential to promote innovative technologies. Even in the United States, such initiatives are not always straightforward: Applied Biosystems was rejected by 19 companies before it eventually got off the ground some 15 years ago. Beneficiaries of Hood's pioneering DNA sequencing technology include Craig Venter (TIGR), whose institute is leading the way in the analysis of human CDNA sequences and the sequencing of entire micro-organism genomes, and Kenichi Matsubara (Osaka), who is focusing on the tissue-specificity of expressed genes. The fortunes of a growing number of companies hinge on the human genetic map, which now consists of more than 5,000 markers (J. Weissenbach, Généthon) and in a few years will embrace most human genes. By contrast, the Human Genome Diversity Project is not faring so well, and yet as Anne Bowcock (U. Texas) pointed out, the concerns of minority groups have failed to recognize that variability within populations greatly exceeds that between populations. Similar accusations of exploitation have been levelled at plant projects, but rapid advances in maize and rice genome research (J. Duesing, Pioneer HiBred; Y. Minobe, NIAR) are promising a new generation of beneficial strains and transgenics.

Nowhere is the rapid pace of gene discovery being felt more than in molecular medicine. Considerable progress has been made in uncovering the genetic basis of many neurological disorders caused by triplet repeats ( $\mathrm{S}$. Tsuji, Niigata University), as well as common disorders such as epilepsy (G. Sutherland, Adelaide) and spinal muscular atrophy (R. Korneluk, Ottawa). But it is in the area of complex diseases that many companies are investing their resources. A popular strategy is to focus on isolated populations where the manifestations of susceptibility genes such as for asthma stand out (T. 


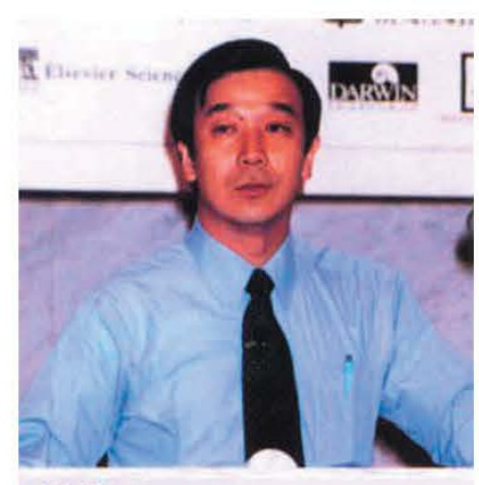

is Division

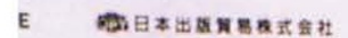
アフコ
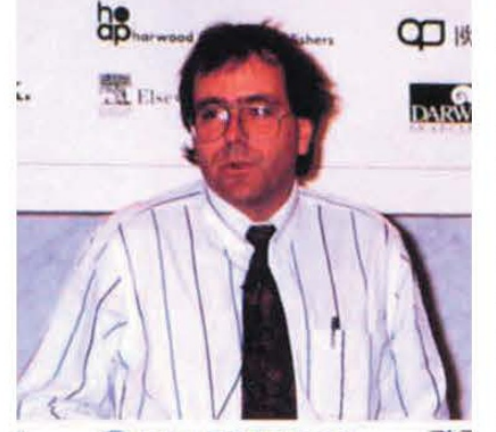

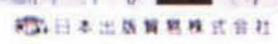

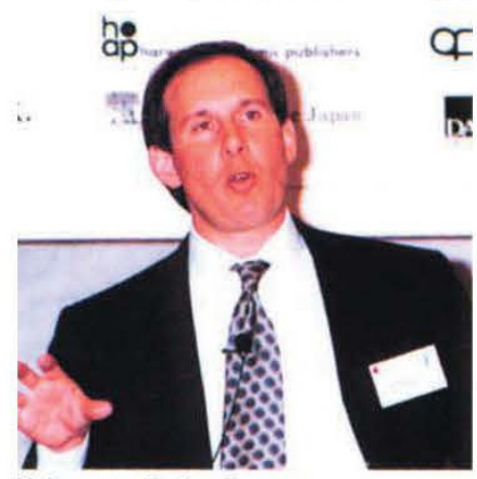

Nakamura, Fodor, Drayna.

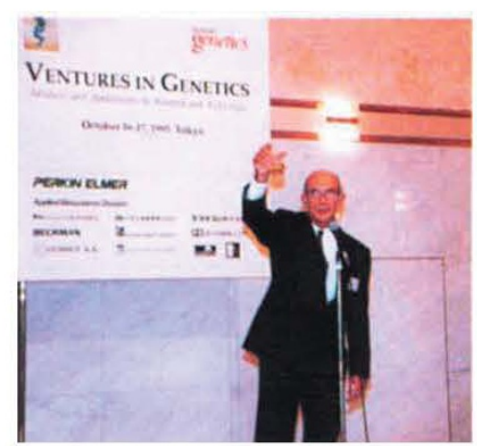

Ray Barker (Macmillan Magazines) toasts the success of Japanese Joint ventures.
Harris, Sequana Therapeutics). Great strides are also being made in cancer research (Y. Nakamura, Tokyo), although alas the regulations of the US Securities and Exchange Commission in connection with stock offerings prevented Alexander Kamb (Myriad Genetics) from divulging too much of his company's progress - Myriad recently raised more than $\$ 50$ million by going public. Screening for many genetic disorders is poised for rapid transformation thanks to advanced technologies such as sequencing by hybridization to DNA oligonucleotides immobilized on microchips (S. Fodor, Affymetrix). Ultimately, the hope is that many fatal disorders will be cured by gene therapy, but even though the field is experiencing growing pains at present, Bob Williamson (Murdoch Institute) argued that new vectors such as artificial chromosomes will eventually succeed the off-the-shelf reagents now commonly in use.

Culture club: One of the few venture capital companies in Japan is AGENE Ltd, which has received funding from the MHW and four pharmaceutical companies. As Dennis Drayna (Mercator Genetics) explained, his company is working with AGENE to isolate the gene for Werner's syndrome, a fascinating disorder of premature ageing about which little is known at the cellular level. The gene was mapped by Drayna and colleagues a few years ago to chromosome 8 , and several groups, AGENE among them, are closing in. But why are such models of business start-up so scarce in Japan? Some of the reasons are deeply embedded in Japanese culture. Yukio Sugino (Takeda Pharmaceuticals) recalled that individuality and creativity were not valued by Confucianism, and similar attitudes permeate Japanese society even today. The loyalty of individual workers to their corporation or government (seen most graphically in the kamikaze during the Second World War) also stifled innovation from within. Other problems include Japan's rigid educational system and the custom of lifetime employment for Japanese workers, neither of which encourage creativity.

A more pragmatic perspective was proffered by Jason Fisherman, a venture capitalist with Advent International - a large US company with liquid resources of some $\$ 3$ billion, provided by institutions, banks and foundations, to develop business by sharing risks and rewards through equity participation. In other words, "Buy low ... sell high!" Fisherman referred to the "intellectual backlog" that has accrued since the late 1970s, which is now being applied by both venture firms and pharmaceutical companies. Increasingly, these organizations are targeting Asia, but Japan does not feature prominently in this market at present. Among the problems are lack of technology transfer mechanisms within universities and a poor grasp among Japanese researchers of patent law (although these deficits are hardly unique to the Japanese). Entrepreneurs are harder to find and good business plans are few and far between. There are also significant differences in pension fund restrictions and capital gains tax laws that hamper private investment. Mitsuru Miyata (Nikkei Biotechnology) felt that Japanese companies and universities are far too eager to import Western technology and science, rather than to foster their own innovative research.

Investment in Japanese biotechnology, noted Yoshihiro Ohtaki, a member of one of Japan's few venture capital companies (Japan Associated Finance Company; JAFCO), is dwarfed by backing of real estate, restaurants and retail. However, the wellreceived plans for two new ventures, obliquely described during the meeting by Junichi Eguchi (MITI), should improve matters. MITI intends to set up the Helix Institute with $\$ 60$ million spread over seven years (see Nature 378, 2; 1995), with support from 13 companies including Hitachi and Mitsubishi Chemical Co. The institute will focus on the physiological function of genes. For the second joint venture, about $\$ 40$ million is being sought from MHW to fund the Pharma-Genocyte Institute, with backing likely to come from Olympus and Kirin Brewery Co. among others. These initiatives deserve to succeed, but that still leaves the daunting task of overcoming the notoriously conservative nature of Japanese society. Sugino illustrated just this,noting ironically that one of the offices at JAFCO displays a saying from the Analects of Confucius: Wa shite, ugokazu - "Acting in harmony, remain still."

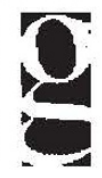

